\title{
Climate as Climax in Shakespeare's Plays
}

\author{
Sophie Chiari (Clermont Auvergne University, Clermont-Ferrand, France)
}

\begin{abstract}
Thanks to the recent advent of ecocriticism in the field of Shakespeare studies, we are becoming increasingly aware that the representation of climate in early modern drama intersects with discourses on crops and food as well as on race and humours. Yet, as climate resists being represented, few critics think of considering its role per se. What did it really bring to early modern audiences?

Keeping in mind the Greek etymology of "climate," klineio or "slope" (i.e. latitude), is quite useful to account for a number of references linked to humoral physiology that prevailed at the end of the $16^{\text {th }}$ century. Unsurprisingly, Shakespeare feels concerned by the ways the local weather durably affects the nature of men as well as by the way their humours are temporarily modified, through the skin, by climate and environment. Yet, I will argue that this very concern actually prompts him to reverse traditional points of view in order to show that things also work the other way round. Indeed, in some of his plays, the playwright insists on men's unfortunate capacities to provoke violent climactic disorders and to generate chaos on earth.

As an example of the interactions between men and weather conditions in Shakespeare's drama, I will explore climate as climax in A Midsummer Night's Dream, Romeo and Juliet, and King Lear. Indeed, in these three works, action is framed by, grounded in, and focused on severe climactic conditions
\end{abstract}

\section{Biographical note}

Sophie Chiari (sophie.chiari@orange.fr) is Professor of early modern English literature at Clermont Auvergne University (Clermont-Ferrand, France). Her last two monographs are entitled As You Like It: Shakespeare's Comedy of Liberty (Presses Universitaires de France, 2016) and Shakespeare's Anatomy of Wit: Love's Labour's Lost (Presses Universitaires de France, 2014). In 2014 and 2015, she edited two collections of essays, Transmission and Transgression: Cultural Challenges in Early Modern England (Presses Universitaires de Provence, 2014) and The Circulation of Knowledge in Early Modern English Literature (Ashgate, 2015). She also wrote the "Robert Greene" entry in The Cambridge Guide to the Worlds of Shakespeare, Volume 1, Shakespeare's World: Shakespeare's World, 1500-1660, (ed. Bruce R. Smith, Cambridge University Press, 2016) and she is currently working on a book project on the question of climate in Shakespeare's plays. 


\section{Climate as Climax in Shakespeare's Plays}

\section{Sophie Chiari (Clermont Auvergne University, France)}

Specialists have shown that, "[th]roughout Europe, the years from 1560 to 1600 were cooler and stormier, with later wine harvests and considerably stronger winds than those of the twentieth century."1 Shakespeare's gives us a clear indication of the impact of such harsh weather on early modern habits, so that it seems worthwhile to explore the relationships between climate and the early modern society as they are represented in Shakespeare's plays. By "climate", I mean weather patterns and fluctuations of long duration. Indeed, in the early modern period, the environment became a privileged locus of scientific debate. References to climate thus often allow us to understand the playwright's engagement with both natural and supernatural phenomena. But there's more to it. Thanks to the recent advent of ecocriticism in Shakespeare studies, we are becoming increasingly aware that the representation of climate in early modern drama intersects with discourses on crops and food as well as on race and humours. Yet, as climate resists being represented, few critics think of considering its role per se.

Shakespeare obviously paid much attention to it, observant as he was of the English climate (famously described by the Constable of France in Henry $V$ as "foggy, raw and dull" [3.5.16]) at a time when differences in race and national character were being accounted for in terms of climate. Keeping in mind the Greek etymology of "climate," i.e. klineio or "slope" (latitude), helps us grasp the meaning of a number of references linked to humoral physiology that prevailed at the end of the $16^{\text {th }}$ century. Unsurprisingly, Shakespeare feels concerned by the ways in which weather may durably affect the nature of men as well as by the way their humours are temporarily modified, through the skin, by climate and environment. Yet, I will argue that his interest in the way weather conditions actually affect human behaviour-an interest shared by many contemporaries - prompts him to modify, and sometimes reverse, traditional points of view in order to show that things also work the other way round. As a consequence, the playwright often insists on men's frightening capacities to provoke violent climactic disorders and to generate chaos on earth. By emphasizing such interactions between men and weather conditions, this essay aims at exploring climate as climax in plays like $A$

\footnotetext{
${ }^{1}$ Fagan, Brian. The Little Ice Age: How Climate Made History, 1300-1850, New York, Basic, 2001, p. 90.
} 
Midsummer Night's Dream, ${ }^{2}$ Romeo and Juliet, ${ }^{3}$ and King Lear. ${ }^{4}$ In these three works, action is indeed framed by, grounded in, and focused on severe climactic conditions.

\section{Cataclysmic weather: A Midsummer Night's Dream}

A Midsummer Night's Dream almost immediately starts with a reference to the moon ("how slow / This old moon wanes," 1.1.3-4), and what is described as a "cold fruitless moon" (1.1.73) by Duke Theseus seems is of prime importance here, were it only because of the presence onstage of the amazon Hippolyta who, even though she is to be married to the Duke, symbolizes aggressive femininity. Moreover, the moon influences the weather on earth (the sublunary world) and, in the play, one of the main tasks of the moon goddess consists in "[d]ecking with liquid pearls the bladed grass" (1.1.211), i.e. in spreading humidity in Athens and its green surroundings.

As a matter of fact, the play mainly offers alfresco scenes emphasizing the influence of nature on the human mind, and Shakespeare probably enhanced this device by having his play performed outside. While a number of critics have suggested that the play was performed for a noble wedding, ${ }^{5}$ the printed text of the comedy actually reveals that it was written for "an outdoor physical structure rather than a hall in a private house. ${ }^{\prime 6}$ For instance, "an entrance at the start of II.i refers to a Fairy entering at 'one door, and Robin Goodfellow at another door'; the central recess in the rear wall (if there was one [...]), covered with a hanging, might have been employed for Titania's bower [...] while the frequent references to the moon might have involved acknowledgement of the decorated roof above the players heads." ${ }^{7}$ Most public stages of the period-including the Globe and the Fortune-were the product of a potent "cosmographic imagination"8 and, in all likelihood, the place (possibly the Theatre) where Shakespeare's Dream was performed must have had a roof protecting the actors from bad weather, with images of the zodiac and of planets painted on the roof's underside.

A spell of particularly bad weather may have affected the performances of the play and echoed its contents, as Shakespeare's Dream ironically depicts nightmarish meteorological

\footnotetext{
${ }^{2}$ William Shakespeare, A Midsummer Night's Dream, ed. Peter Holland, Oxford, Oxford University Press, 1995.

${ }^{3}$ William Shakespeare, Romeo and Juliet, ed. Jill L. Levenson, Oxford, Oxford University Press, 2000.

${ }^{4}$ William Shakespeare, King Lear, ed. R.A. Foakes, London, Thomson Learning, The Arden Shakespeare, 1997.

${ }^{5}$ Peter Holland, "Introduction" in A Midsummer Night's Dream, ed. cit., p. 111-12.

${ }^{6}$ Martin White, The Shakespeare Handbooks. A Midsummer Night's Dream, New York, Palgrave Macmillan, 2009, p. 6.

${ }^{7}$ Ibid.

${ }^{8}$ John Gillies, Shakespeare and the Geography of Difference, Cambridge, Cambridge University Press, 2014, p. 70.
} 
conditions. 'Real' rain or fresh temperatures may therefore have produced an interesting sense of realism, prompting the spectators to sympathize with the plight of the characters. Temperatures had begun to drop around the beginning of the fourteenth century (after a 400year warm medieval period). ${ }^{9}$ The 1590 s were notably cold. ${ }^{10}$ Indeed, during this period, the temperature was in average about two degrees Fahrenheit lower than it had been in previous centuries. $^{11}$

Theologians were then keen to supply religious explanations for these unsettling natural phenomena. Luther, for example, argued that the Fall of Adam affected not only man but also nature. The whole of creation was degenerated into natura corrupta, a corrupted nature. About Genesis $(3,1)$, he explained that "[a]ll these things are deformed after the (original) sin, so that all creatures, even the sun and the moon looked as if they were put in a sack..." ${ }^{12}$ With the subsequent destruction of the world by the Flood, the situation became even worse. Such a view of the deluge as a catalyst for speeding up the world's decay was very common in Renaissance thinking, especially in the tradition of pessimistic cosmologies seeing the earth as an ageing world. ${ }^{13}$

A Midsummer Night's Dream questions this tradition as the first climax in the play is Titania's famous monologue, in act 2 , scene 1 , on the poor climate and on natural catastrophes that structures the comedy as a whole. The Queen of Fairies, who always sounds quite humanlike, can of course be seen the nocturnal counterpart of Hippolyta-the two roles are often doubled onstage. ${ }^{14}$ Now, at the beginning of the Dream, she itemizes a whole catalogue of disasters, including fog, flooding, failed crops, miserable flocks, polluted air, bad temperatures, rheumatic diseases, all due to the wet climate:

Therefore the winds, piping to us in vain,

As in revenge, have sucked up from the sea

\footnotetext{
${ }^{9}$ The world would be warming again only by the early 1800 s.

${ }^{10}$ Brian Fagan, The Little Ice Age: How Climate Made History, 1300-1850, New York, Basic, 2001, p. 90. The years between 1680 and 1730 were also particularly cold.

${ }^{11}$ This decrease was large enough to leave Iceland completely surrounded by ice and to freeze the Thames in England while the canals in Holland were routinely frozen. See Emily Oster, "Witchcraft, Weather and Economic Growth in Renaissance Europe," Journal of Economic Perspectives 18.2 (Winter 4004) p. 218.

12 "Haec omnia post peccatum deformata sunt, ita ut creaturae omnes, etiam Sol et Luna quasi saccum induisse videantur..." Martin Luther, "Vorlesungen über 1. Mose" in Kritische Gesamtausgabe 42-44, Weimar, Böhlau 1911-1913, vol. 42, p. 68. Quoted in Michael Kempe, "Noah's Flood: The Genesis Story and Natural Disasters in Early Modern Times," Environment and History, Vol. 9, No. 2, Coping with the Unexpected - Natural Disasters and their Perception (May 2003), p. 152 (pp. 151-171).

${ }^{13}$ Michael Kempe, "Noah's Flood," p. 152.

${ }^{14}$ We cannot assert that such a practice was adopted by Shakespeare's company, but the doubling of Hippolyta and Titania was done as early as 1661. See Peter Holland's Introduction in A Midsummer Night's Dream, p. 96.
} 
Contagious fogs which, falling in the land

Have every pelting river made so proud

That they have overborne their continents.

The ox hath therefore stretched his yoke in vain,

The ploughman lost his sweat, and the green corn

Hath rotted ere his youth attained a beard.

The fold stands empty in the drownèd field,

And crows are fatted with the murrain flock.

The nine-men's-morris is filled up with mud.

[...].

Therefore the moon, the governess of floods,

Pale in her anger washes all the air,

That rheumatic diseases do abound;

And thorough this distemperature we see

The seasons alter: hoary-headed frosts

Fall in the fresh lap of the crimson rose,

And on old Hiems' thin and icy crown

An odorous chaplet of sweet summer buds

Is, as in mockery, set. The spring, the summer,

The childing autumn, angry winter change

Their wonted liveries, and the mazèd world,

By their increase, now knows not which is which;

$[\ldots]$.

(2.1.81-117)

In this well-known piece, Titania offers a syncretic description which is both evocative of the world-wide inundation described by Moses in Genesis (6-9) and of the Tartarus as described, for example, by Francis Bacon in the Wisdom of the Ancients, i.e. "a place signifying perturbation [...] between the lower superficies of heaven and the centre of the earth, in which all perturbation and fragility and mortality or corruption are frequent." ${ }^{15}$ Far from being edenic, Shakespeare's green world is presented as an anti-pastoral one marred by chaos and bad weather.

Yet, although she inhabits this rather hostile milieu, Titania does not portray herself as a victim. By contrast, in other plays of the period, characters enduring bad weather often

\footnotetext{
${ }^{15}$ Francis Bacon, Wisdom of the Ancients, trans. Arthur Gorges, London, 1619, chap. XII, p. 232.
} 
present themselves as passive subjects. In Samuel Daniel's pastoral drama, The Queenes Arcadia (c. 1606), two shepherds voice their concerns about climate change and they clearly see themselves as the main victims of the harsh weather affecting England:

And me thinks too our very aire is changed

Our wholesome climate grown more maladive

The fogges and syrene offend us more

(Or we made think so) than they did before. ${ }^{16}$

The "syrene," which refers here to a "light fall of moisture or fine rain after sunset in hot countries $[\ldots]$ formerly regarded as a noxious dew or mist" (OED, "serene," n.), ${ }^{17}$ is evocative of a potentially harmful climate likely to weaken even the strongest of men. Pointing out the fallen state of manhood, this lament about the poor English weather apparently summarizes Titania's arguments in The Dream except that the Queen of the Fairies does not actually blame the weather for the topsy-turvy state of her green realm. On the contrary, she claims joint responsibility with her husband for the disruption of the natural cycles. They alone, she says, are the direct cause of this disturbance of the seasons and of the floods and storms that have destroyed the crops and ruined the agrarian economy of fairyland.

So, the weather is not the source but the consequence of discord. The reason is Titania's attachment to the child of her votaress who died in childbirth ("she, being a mortal, of that boy did die," 2.1.135) and her battle against Oberon for the possession of the "changeling boy" (2.1.120). So, up to a point, we can say that it is Titania's lack of self-discipline and selfrestraint ${ }^{18}$ which has generated the chaotic weather she describes. Her misdemeanour has made Oberon jealous of the little Indian boy and, as a result, their relationship has become discordant and tumultuous. This marred relationship has direct consequences on the weather. In the Symposium, Plato emphasizes this causal link and clearly associates ideal love to a temperate climate:

\footnotetext{
${ }^{16}$ Quoted by Todd A. Borlik, Ecocriticism and Early Modern English Literature. Green Pastures, New York, Routledge, 2011, p. 128. Borlik compares this excerpt from Daniel's play with "Lear's harangue imploring the winds to rage and the rains to deluge the earth" which, according to him, may have sounded like "an inversion of the Rogation liturgy".

${ }^{17}$ The first use of the word quoted by the $O E D$ dates back to 1591 as John Florio mentioned the "Seren" in his Second Frutes: "The Seren neuer hurts a man in these colde countries."

${ }^{18}$ On women's supposed lack of self-control, see Michael C. Schoenfeldt, Bodies and Selves in Early Modern England: Physiology and Inwardness in Spenser, Shakespeare, Herbert, and Milton, Cambridge, Cambridge University Press, 1999, p. 36. Lemnius is also quoted.
} 
When the elements to which I have already referred — hot and cold, wet and dry—are animated by the proper species of Love, they are in harmony with one another: their mixture is temperate, and so is the climate. Harvests are plentiful; men and all other living things are in good health. ${ }^{19}$

Because there is no such thing as harmonious love in A Midsummer Night's Dream, the climate of fairyland is disrupted. We could even add that the mischievous Puck, a Cupid-like figure at work in the woods, proves the impossibility of concord in such an unstable environment. Rather they strengthening the couples, he weakens them and makes them err in the labyrinthine forest of Athens. In an intriguing way, Puck prefigures the Cupid described by Francis Bacon in the Wisdom of the Ancients, a text which presents the ever-shifting god of love as an atom. ${ }^{20}$ Cupid - and Puck, for that matter-is always "elegantly described with perpetual infancy or childhood" and similarly, "the first seeds of things or atoms, they are little and diminute, and always in their infancy." ${ }^{21}$ In other words, like the atoms evoked in Lucretius' De rerum natura, Puck perpetually moves in a vacuum where he freely exerts his power on the outside world. Shakespeare's Dream thus seems to be atomist avant la lettre, something particularly worth noting in connection with King Lear, another anti-pastoral, albeit much darker, play which will be studied later on in this essay.

For the time being, let us note that humidity and coldness are prevalent not only in the not so idyllic Athenian woods, but in the world in general. We learn that, in the west, there has been a flood "fill[ing] up with mud" the "none men's morris" (2.1.99), and in the east (the motherland of the stolen Indian child), the "wanton wind" (2.2.129) keeps blowing and makes the sea rough. As a result, moisture is prevalent in the world of the comedy, so much so that secondary characters are not immune from it. Amusingly, on learning that Pyramus is "[a] lover, that kills himself, most gallant, for love" (1.2.20), Bottom decides that the role "will ask some tears in the true performing of it" (1.2.21-22). Even the Dream's metaphoric language is pregnant with allusions to humidity. Saddened by her father's hostility towards Lysander, Hermia mentions "the tempest of [her] eyes" (1.1.129), and Helena laments the behaviour of her beloved Demetrius, who "hailed down oaths that he was hers" (1.1.243) before suddenly changing his mind:

And when this hail some heat from Hermia felt,

\footnotetext{
${ }^{19}$ Plato, Symposium 2 trans. Alexander Nehamas and Paul Woodruff, in Complete Works, ed. John M. Cooper, Indianapolis, Hackett, 1997, p. 471.

${ }^{20}$ It should be made clear at this point that Bacon was much interested in the atomistic philosophy of Democritus and quoted Lucretius in several of his works.

${ }^{21}$ Francis Bacon, Wisdom of the Ancients, chap. XVII, p. 241.
} 
So he dissolved, and showers of oaths did melt.

$(1.1 .244-45)$

This general moisture turns the forest into a feminine landscape (dis)ordered by Titania. Indeed, women were then considered as leaky vessels and their moist, lunar physiology accounted for their alleged lack of reason. In The Secret Miracles of Nature, originally published in 1561, the Dutch physician Levinus Lemnius writes that

[...] women are subject to all passions and perturbations [...] a woman enraged, is besides her selfe, and hath not power over her self, so that she cannot rule her passions, or bridle her disturbed affections, or stand against them with force of reason and judgement $[\ldots]^{22}$

Although it was translated into English in the second half of the $17^{\text {th }}$ century, Lemnius' work circulated in Latin from the 1560s onwards and its views were highly influential among the literati of the period. Whether Shakespeare knew it or not, in the Dream, nature clearly represents female agency. It is in essence a feminine and destructive force. Even Hiems, the masculine Winter King embodying old age, is mocked and vanquished by Nature:

And on old Hiems' thin and icy crown

An odorous chaplet of sweet summer buds

Is, as in mockery, set. [...]

(2.1.110-11)

If these disorders are thus linked to women's misrule, they are also part and parcel of the world upside down of comedy and they trigger off the carnivalesque impulses of the lovers and of the mechanicals later on in the play.

So far, we have seen that, in The Dream, it is Titania's surprisingly human behaviour which accounts for the harshness of the climate. Shakespeare, as a result, questions and reverses traditional thinking related to the early modern climate. In other words, by emphasizing the weather as a consequence rather than as a cause of chaos, Shakespeare deconstructs the idea that meteorology aided in explaining human behaviour.

\section{Romeo and Juliet and the dog days}

\footnotetext{
${ }^{22}$ Levinus Lemnius, The Secret Miracles of Nature, London, 1658, p. 273-74.
} 
Not everywhere, though, does the playwright so blatantly question the traditional thoughts related to the early modern vision of climate. Romeo and Juliet, which has often been seen as The Dream's companion piece, presents for example a very different approach to climatology — one that incorporates traditional and, above all, astrological beliefs.

If we accept the fact that the seasons are the "climactic presentation of the passage of time,", 23 then it is useful to study Romeo and Juliet through the prism of seasons. Only one of them is mentioned, which suggests that, far from being tied to nature's cycles and, therefore, to procreation, the setting of the tragedy is associated with standstill and sterility. Summer appears to be a climactic time of the year in Verona and it precludes the advent of all other seasons. This is quite surprising for at least two reasons. Firstly, as I have just explained, Shakespeare seems to have lived in a rather cold age. Secondly, the sources of Romeo and Juliet actually rely on an imagery of snow and ice. In Le Novelle del Bandello (1554), the lovesick Romeo is so depressed that he wastes away "like snow in the sun,"24 and in Arthur Brooke's The Tragicall Histoyre of Romeus and Juliet (1562), the ball organized by old Capulet takes place in the winter season:

The wery winter nights restore the Christmas games,

And now the season doth invite to banquet townish dames.

$(1.155-56)^{25}$

This contrasts strongly with the summer imagery predominant in Shakespeare's play, which shows, if anything, that his works should not be read as scientific reports but as aesthetic enterprises capitalizing on popular topics. What's more, as noted by Mary Floyd-Wilson, the English mainly saw themselves as Northerners: "England's northern climate and the English people's northern status colored their perspective on everything from fashion to medicine to politics. ${ }^{26}$ By changing the cold background of the initial storyline, Shakespeare defamiliarized it, thereby creating an effect of distantiation (while, as has been suggested

\footnotetext{
${ }^{23}$ Tripthi Pillai, "New Directions: 'Constructing Experiences and Charting Narratives: The Future in/of $A$ Midsummer Night's Dream" in A Midsummer Night's Dream: A Critical Guide, ed. Regina Buccola, London, Continuum, Continuum Renaissance Drama, 2010, p. 153 (150-71).

${ }^{24}$ Quoted in “'A Plague 'o Both Your Houses': Shakespeare and Early Modern Plague," A Dissertation presented by Nichole DeWall, Northeastern University, Boston, April 2008, p. 69.

${ }^{25}$ Geoffrey Bullough, Narrative and Dramatic Sources of Shakespeare, vol. 1, London, Routledge and Kegan Paul, 1961, p. 290. See, too, 1. 949-50, p. 310: "The summer of their blisse, doth last a month or twayne / But winters blast with spedy foote doth bring the fall agayne."

${ }^{26}$ Mary Floyd-Wilson, English Ethnicity and Race in Early Modern Drama, Cambridge, Cambridge University Press, 2003, p. 4.
} 
above, he chose an opposite strategy in A Midsummer Night's Dream, composed at about the same time as Romeo and Juliet). His modification had the double advantage of adding a touch of novelty to his retelling and of allowing him to go much further than someone like Brooke in the exploration of hatred and passion. To put it simply, the new context now precluded any identification from an audience who would have been reluctant to recognize themselves either in the old Capulet couple or in a pair of young lovers doomed to death right from the very start.

Shakespeare's hell on earth is therefore hot and dry, in this tragedy, and love is first and foremost seen as a burning pain:

\section{Benvolio [to Romeo]}

Tut, man, one fire burns out another's burning,

One pain is lessened by another's anguish;

$[\ldots]$

$1.2 .45-46$

Incidentally, in the tragedy, Capulet's only surviving child owes her name to her being born on the last day of July, on the $31^{\text {st }}$, on the eve of Lammastide (i.e. the harvest festival which took place on August, $1^{\text {st }}$ ). ${ }^{27}$ When she is asked to give Juliet's exact age, the Nurse repeatedly quibbles on the specific acoustics of Juliet's name which she parses as 'Jule'/‘Ay':

Thou wilt fall backward when thou hast more wit,

Wilt thou not, Jule?' And, by my halidom,

The pretty wretch left crying and said ' $A y$ '.

To see now how a jest shall come about!

I warrant an I should live a thousand years,

I never should forget it. 'Wilt thou not, Jule?' quoth he,

And pretty fool, it stinted and said ' $A y$ '.

$[\ldots]$

Will thou not, Jule?' It stinted and said 'Ay'.

(1.3.44-59, my emphasis)

I'm not saying here that, in absolute terms, Juliet's name derives from the month of her birth, since she is already called Juliet in Brooke's Tragicall Historye of Romeus and Juliet and

\footnotetext{
${ }^{27}$ As the Nurse puts it (“On Lammas Eve at night shall she be fourteen”, 1.3.23).
} 
Julietta in Bandello's earlier story. I just want to argue that, if Shakespeare changed the season of his sources and chose the month of July, it was probably to reinforce the echo to Juliet's name and to insist on her predestined fate. ${ }^{28}$

In the following scene, Juliet is said to "han[g] upon the cheek of night / As a rich jewel in an Ethiop's ear" (1.4.158-59). The word "jewel" functions here as the acoustic double of "Jule" and makes Juliet's name resonate once more throughout the play. ${ }^{29}$ Besides, these lines actually convey an erotic blazon, an astrological emblem and a sign of discordia concors. As often in Shakespeare, such complex and beautiful imagery is not gratuitous and ties in with the references to summer and heat that pervade the play as a whole. Indeed, the allusion to the Ethiop's ear does not simply connote sensuality, it also evokes the Ovidian myth of Phaeton. Ovid's fable was indeed the first to express fears about growing heat and climate change, fears that were often associated with apocalyptic visions of a world destroyed by fire. In Arthur Golding's translation, one of the marginal notes of the Phaeton episode refers to the following quotation as "the burning of the world" 30 (Golding 2002, 69):

The restless horses of the sun, began to neigh so high

With flaming breath that all the heavens might hear them perfectly.

$[\ldots][\ldots]$ they left the beaten way

And, taking bridle in their teeth, began to run astray.

$[\ldots]$

Then wheresoever Phaëton did chance to cast his view,

The world was all on flaring fire. The breath the which he drew

Came smoking from his scalding mouth as from a seething pot;

His chariot also under him began to wax red-hot.

He would no lenger dure the sparks and cinders flying out.

Again, the culm and smouldering smoke did wrap him round about,

The pitchy darkness of the which so wholly had him hent

As that he wist not where he was nor yet which way he went.

The wingèd horses forcibly did draw him where they would.

The Ethiopians at that time (as men for truth uphold),

\footnotetext{
${ }^{28}$ Cf. King Lear, where the bastard's view (1.2.119-30) corresponds to the cynical naturalist or materialistic stance that, contrary to Romeo and Juliet, where the influence of the dog days, or Canis maior, and the questions of date, calendar and nativity as well as conception are presented as crucial elements that determine the tragic events of the play.

${ }^{29}$ On this, see François Laroque, "Roméo et Juliette, entre violence et jouissance," Revue Silène, 2007, p. 13 (p. 1-14). Website: http://www.revue-silene.com/images/30/extrait 88.pdf (Date accessed: 17 July 2016).

${ }^{30}$ Arthur Golding (trans.). Ovid's Metamorphoses Translated by Arthur Golding, ed. Madeleine Forey, Baltimore, The Johns Hopkins University Press, (2001), 2002, p. 69.
} 
The blood by force of that same heat drawn to the outer part

And there adust from that time forth, became so black and swart.

(The Second Book, 11. 203-301) 31 $^{31}$

This climactic myth, which provides its own explanation for the apparition of the black race, ${ }^{32}$ is indeed a necessary complement and context to the summer imagery in Romeo and Juliet. Set during the dog days of summer, the tragedy completely reverses the pattern established in A Midsummer Night's Dream-unless it is The Dream that turns upside down the weather pattern informing Romeo and Juliet. While in the comedy, misrule affects the weather, misrule in the tragedy is caused by the weather, and climate, therefore, acts as an agent of fate.

Indeed, hot temperatures loom large in the play. Mercutio, for instance, complains to Romeo and Benvolio that they "burn daylight" (1.4.41) - i.e. waste time-, and Friar Laurence, collecting plants in the early morning, anxiously anticipates the sun's "burning eye" (2.2.4). Even more significantly perhaps, the Nurse associates the letter " $R$ " not with Romeo, but with "the dog's name" (2.3.198), thereby alluding to the dog-days that are plaguing the city of Verona. ${ }^{33}$ These days were not only seen as the hottest ones of the year, they were also thought of as the unhealthiest. ${ }^{34}$ So, when, during the ball, Old Capulet complains that "the room is grown too hot" (1.4.141), he actually delivers a proleptic observation paving the way for the play's tragic outcome. Ironically, the "fire" mentioned here points both backward to Shakespeare's main sources, Brooke and Painter, who depicted a Christmas feat, and forward to the consuming passion of the star-crossed lovers.

Interestingly enough, and in connection with the sense of doom pervading the play, the expression "dog-days" combines climatology and astrology. Indeed, it derives from the dogstar called Sirius, which rises about the same time as the sun in August. In popular stellar calendars of the period such as Hyginus fabularum liber (Basel, 1549), ${ }^{35}$ the end of July and most of the month of August were depicted as 'canicular' because these months coincided

\footnotetext{
${ }^{31}$ Ibid., p. 66-69.

${ }^{32}$ Cf. Rabelais' Pantagruel (1532), chapter 2.

${ }^{33}$ The dog-days were a time of dramatic climactic extremes, and Shakespeare also mentions them in other plays. In King Henry VIII, for example, the dog-days of summer, from mid-July to mid-August, are evoked.

${ }^{34}$ As part of an unsettled weather, hot temperatures could be an indirect cause of death insofar as it "delay[ed] planting or harvesting," which had "dire consequences for much of a population in a given region." See Robert Markley, Robert Markley, "Summer's Lease: Shakespeare in the Little Ice Age" in Early Modern Ecostudies: From the Florentine Codex to Shakespeare, eds. Ivo Kamps, Thomas Hallocks, and Karen Raber, New York, Palgrave Macmillan, 2008, p. 136 (p. 131-42).

${ }^{35}$ Caius Julius Hyginus, Fabularum liber [et alia opera], Basileae, per Ioannem Hervagium, Anno 1549. Mense Martio. (Basileae, per Ioannem Hervagium, Anno salutis humanae M. D. XLIX. Mense Martio)
} 
with the rising of Sirius, the chief star of the constellation "Laelaps," or Canis Major. ${ }^{36}$ Sirius was placed at the tip of the constellation of Canis Major, and it was thus visually associated "with a descent into the jaws, or mouth, of death.",37

The life and behaviour of the "star-crossed" lovers is thus deeply influenced by Sirius, and it then comes as no surprise that they should react so angrily and passionately against their parents. As a matter of fact, Sirius was associated with hot temperatures and the physicians of the time thought that heat was the main cause of an increase of the choleric humour. William Clever, for instance, explained in 1590 that if winter usually stifled angry feelings, the hot months of the year triggered man' choler:

Cornelius Celsus saith, that like as the sunne is lodged vnder the darke vaines of the clouds, in the night season, so heat is hidde and shrowded in the secrete vaines of all thinges in winter, and waxeth more outward and stronger with the in|crease of the yeare, vntill by the temperature of the sunne it bee powerfull and mightie.

Arnoldus de noua villa affyrmeth, that the complexion of man ariseth and falleth, with the temperature or distemperature of the yeare: so may we gather hereby that choller rageth and super aboundeth more in sommer then winter, only by an intentiue qualitie. ${ }^{38}$

In Shakespeare's tragedy, yellow bile ${ }^{39}$ and ardour prompt the actions of the main characters who are presented as the victims of an already written destiny. Romeo, for example, is depicted as a "distempered head" by Friar Laurence (2.2.33) — “distempered" evoking in this case "an imbalance in the bodily 'humours' of blood, phlegm, choler and melancholy [...]". 40 Even more significantly, in the play's opening scene, Samson and Gregory pun on "colliers" ("colliers" designating both "those who carry coals" and "dog collars" in French). Doing so, they associate "colliers" with "choler" and with "dogs" (1.1.2-7). Such an emphasis laid on dog-days and choler is in fact programmatic and the same association keeps reappearing from scene to scene throughout the play. ${ }^{41}$ So, whereas The Dream examines innovative modes of

\footnotetext{
${ }^{36}$ Ibid., Liber III, p. 93.

${ }^{37}$ Philippa Berry, Shakespeare's Feminine Endings: Disfiguring Death in The Tragedies, London, Routledge, 1999 , p. 37.

${ }^{38}$ William Clever, The flower of phisicke VVherein is perfectlie comprehended a true introduction and method for mans assured health: with three bookes of philosophie for the due temperature of mans life. In which easily may be perceiued the high \& wonderfull workes of God in the gouernance of all thinges. Written by W.C. as a glasse of true knowledge for the better direction of al willing [et] vertuous practitioners, London, 1590, STC ( $2^{\text {nd }}$ ed.) / 5412, p. 96.

${ }^{39}$ By the early $16^{\text {th }}$ century, yellow bile was the most common term for the choleric humour.

${ }^{40}$ Shakespeare, Romeo and Juliet, ed. René Weis, London, Bloomsbury, Arden Shakespeare, Note to line 29 , 2012, p. 203.

${ }^{41}$ Later on in the play, in 1.4 , Tybalt mentions once against choler in connection with "patience perforce"
} 
thought, Romeo and Juliet obviously stems from a medieval conception of the world, according to which fundamental elements, i.e. ignis, aer, aqua, and terra, were believed to organize, operate within and influence human, animal and vegetal bodies.

\section{King Lear: Dislocating weather}

Choler in also present in King Lear, an acousmatic ${ }^{42}$ play full of lightning and thunder. While thunder had natural causes in early meteorology-Aristotle claimed that it arose from a "collision" between dry and moist exhalations ${ }^{43}$ - the wrath of God was often invoked to account for the occurrence of natural calamities. ${ }^{44}$ The idea of explaining a particularly harsh weather by God's anger went of course hand in hand with the concept of providence. The problem is that providence is absent from King Lear, a play offering a nihilistic and deeply pessimistic vision of humankind. Its apocalyptic language and images do not signal the wrath of God: they actually signify his absence.

Now, one may wonder here what happens in Shakespeare's direct source, i.e. The True Chronicle History of King Leir (1605). This source highlights a providential order. Indeed, in the old play of Leir, "a 'Messenger or murthere' is instructed by Ragan to kill Leir and Perillus [who becomes Kent in Shakespeare's version]. He is about to do so. Leir and Perillus try to dissuade him. Perillus describes to him the plans of hell, and at that moment it thunders'. The messenger 'quakes, and lets fall the Dagger'."45 In Shakespeare's play, there is no god behind the storm. Thunder acts as a consciousness-raiser, which leads Lear to a new understanding of the reality around him. He is literally enlightened by the flashes of lightning when the sun had always blinded him.

\footnotetext{
(1.4.202).

42 "Acousmatic" because the source of the noise remains unseen.

${ }^{43}$ Aristotle, Meteorologica, trans. H.D.P. Lee, Cambridge, Mass., Harvard University Press, Loeb Classical Library, 1978, II.IX, p. 231: “Our own view is that the same natural substance causes wind on the earth's surface, earthquakes beneath it, and thunder in the clouds; for all these have the same substance, the dry exhalation. If it flows in on way it is wind, in another it causes earthquake; and when clouds change in the process of contracting and condensing into water, it is ejected and causes thunder and lightning [...].”

${ }^{44}$ This is the case, for instance, in a work such as The last terrible Tempestious windes and weather (London, 1613).

${ }^{45}$ John Dover Wilson's Introduction in William Shakespeare, King Lear, ed. John Dover Wilson, Cambridge, Cambridge University Press, 1960, 1968, p. xxxvi.
} 
So, it seems that Shakespeare refuses and refutes any idea of divine intervention: far from being supernatural, as is sometimes apparently the case in The Tempest for instance, thunder is the voice of a harsh Nature endowed with human features. ${ }^{46}$

I would like to argue here that this implicit insistence on natural causes is strongly reminiscent of the first-century poem by Lucretius, De rerum natura, already briefly mentioned in the first part of this essay. ${ }^{47}$ Shakespeare knew of this philosophical poem thanks to the numerous extracts contained in Montaigne's Essays as translated by John Florio. ${ }^{48}$ Consequently, the prevalence of weather images in this play probably owes much to his interest for Lucretius's use of meteorological models in order to explain the creation and disintegration of material objects and living beings.

Lear's appeal to the "oak-cleaving thunderbolts" (3.2.5) threatening his frail white head during the famous episode of the storm on the heath is undoubtedly the climax of the tragedy. Interestingly, this climactic climax contains an inescapable reference to Lucretius' semina rerum (i.e. combinations of atoms endowed with formative powers from which natural bodies originate): "Crack nature's moulds, all germens spill at once / That makes ingrateful man" (3.2.8-9). ${ }^{49}$ Lear, here, aims at annihilating both the feminine ("moulds") and the masculine ("germens") principles of creation at once. Earlier on in the play, the old King's retort to Cordelia also alludes to Lucretius: "Nothing will come of nothing" (1.1.90) - a principle barely rephrased a few scenes later as "Nothing can be made out of nothing" (1.4.130). Such statements clearly echo the principles of atomism, according to which "nothing can ever be created by divine power out of nothing. ${ }^{, 50}$ If the Biblical God created the world ex nihilo, the

\footnotetext{
${ }^{46}$ The treatment of the storm is different in a play like The Tempest. In the first scene, the storm looks natural. But its significance shifts and, in 3.3, during the banquet, the storm comes to represent "a commonplace theophany which revels in its theatrical tricks." In other words, the storm would gradually turn into a sign revealing the presence of a divine power to an amazed audience of shipwrecked survivors. See Gwilym Jones, "Storm Effects is in Shakespeare" in Shakespeare's Theatres and the Effects of Performance, eds. Farah Karim Cooper and Tiffany Stern, London, Bloomsbury, The Arden Shakespeare, p. 50.

${ }^{47}$ The following development owes much to Jonathan Pollock, "Of Mites and Motes: Shakespearean Readings of Epicurean Science" in Spectacular Science, Technology and Superstition in the Age of Shakespeare, eds. Sophie Chiari and Mickaël Popelard, forthcoming.

${ }^{48}$ Montaigne relied on the following edition of De rerum natura: Dionysius Lambinus, Titi Lucretii Cari De rerum natura libri sex, Paris - Lyon, Rovillium [Guillaume Rouillé and Philippe Rouillé], 1564.

${ }^{49}$ As Antonio Clericuzio remarks, "[t]he use of seeds in Greek cosmology can be traced back to Anaxoras, who maintained that all natural bodies are generated from specific seeds. In Epicurus and Lucretius the notions of sperma and semen are equivalent to atomos. Epicurean atoms were not inert, but conceived as units of matter endowed with activity." See Antonio Clericuzio, Elements, Principles and Corpuscles. A Study of Atomism and Chemistry in the Seventeenth Century, Dordrecht, Springer, 2000, p. 14.

${ }^{50}$ See Lucretius [Titus Lucretius Carus], On the Nature of the Universe, trans. R. Latham, Harmondsworth, Penguin Classics, 1955, 1.545-47: "But, since I have already shown that nothing can be created out of nothing nor any existing thing be summoned back to nothing, the atoms must be made of imperishable stuff into which everything can be resolved in the end, so that there may be a stock of matter for building the world anew." For
} 
atomists deny the power of the gods in the creation of the universe. According to them, everything is the result of fortuitous assemblages of atoms, but in order to meet and combine with one another, these atoms must be eternal, their number infinite and their movement perpetual.

This being said, it is worth noting that the characters in King Lear are far from having acquired that quietness of mind which the Epicureans called "ataraxia" (i.e. non-agitation). Rather, most are "minded like the weather, / Most unquietly" (3.1.2-3). And yet, in spite of his low morale, Lear remains quite positive when he addresses Edgar-as-Poor Tom as a "Noble philosopher" and a "good Athenian." 51 This makes sense if one remembers that De rerum natura also celebrates "A Greek mortal, [who] dared oppose religious dogma; nothing stopped him, neither the reputation of the gods, nor thunderbolts, nor the threatening grumble from the skies." 52 This unnamed mortal is probably the Greek philosopher Epicurus. In Shakespeare, Lear takes the opportunity of asking the "good Athenian" the "the cause of thunder" (3.4.151), seeking to know whether he is right to assign to it supernatural causes: is it really "the great Gods / That keep this dreadful pudder o'er our heads" (3.2.49-50)? ${ }^{53}$ In the last two books of De rerum natura, Lucretius concludes that meteorological phenomena y general, including thunder and lightening, have only natural causes. So, it was "ignorance of the true causes that persuaded men to confer upon the gods the empire over all things and to concede royalty." 54 If one keeps these considerations in mind, one may say that the representation of the weather, in King Lear, is heavily dependent on Lucretius' approach.

The climate is actually so harsh in the tragedy that Shakespeare seems to depict, albeit metaphorically, a "climactericall" year. In Randle Cotgrave's Dictionarie, the word "climactere" or "climatericall" is defined as follows:

further comments on Shakespeare's borrowing here, see Richard Allen Shoaf, Lucretius and Shakespeare on the Nature of Things, Newcastle upon Tyne, Cambridge Scholars Publishing, 2014, p. 11.

${ }^{51}$ Given Poor Tom's way of life and near nakedness, scholars generally assume that King Lear equates him with the ancient Greek Cynical philosophers Diogenes or Crassus, even though Lear is supposed to live before their time.

${ }^{52}$ Lucretius [Titus Lucretius Carus]. On the Nature of the Universe, ed. cit., 1.66-68.

${ }^{53}$ Epicurus examines the same question in his letter to Pythocles, in which he explains that thunder is not due to any divine action, but is probably caused by the wind rolling in the clouds' hollow parts, for instance. See Epicurus, Letter to Pythocles, in Diogenes Laertius, para. 100, trans. R.D. Hicks, London and Cambridge, Mass., Loeb Classical Library, 1958.

${ }^{54}$ Lucretius, Titi Lucreti Cari De Rerum Natura Libri Sex, ed. Cyril Bailey. Oxford, Clarendon, 1947, 6.54-55: "[...] ignorantia causarum conferre deorum / cogit ad imperium res et concedere regnum." The English translation is that of Jonathan Pollock in "Of Mites and Motes." 
Climactere: com. Climatericall; whence; L'an climactere. The Climatericall year; everie seventh, or ninth, or the 63 yeare of a mans life; all very dangerous, but the last, most. ${ }^{55}$

The concept of dangerous climactericall years came from Greek astrology, in which it had previously been imported from Egyptian and Chaldean traditions. ${ }^{56}$ Aged over 80 years old, Lear is definitely older than 63 , but he belatedly goes through a climactericall year of sorts which makes him endure all sorts of calamities.

Up to a certain point, these calamities must have been familiar to Shakespeare's audience, as had already been the case with A Midsummer Night's Dream. Spectators could therefore easily identify with Kent, horrified by "Such sheets of fire, such bursts of horrid thunder, / Such groans of roaring wind and rain [...]" (3.2.46-47), all the more so as appalling storms devastated England and Northern Europe in the spring of 1606. An eyewitness reports for instance: "The nine and twentieth, and thirtieth of March [1606], the wind was so extraordinary great and violent, that it caused great shipwreck... it also caused the sea, and divers rivers to overflow their bounds, and drowned many people, and much cattle."57

As a consequence, critics like Robert Markley have argued that "Lear is not wandering through a metaphoric storm that marks his poetic madness and signals the disruption of the natural order but an all-too recognizable figure who registers the complex connexions between climactic instability and its potential consequences: the loss of agricultural harvests and the fracturing of ideologies of national unity, patriarchal authority, and socioeconomic stability." ${ }^{58}$ Stripping the storm off its metaphoric connotations amounts to making climate almost tangible onstage and, as it were, to turning it into a place or "a portion of the world, betweene South and North," in the terms of Randle Cotgrave. ${ }^{59}$ It is indeed tempting to read King Lear as a reflection of the real since, as noted by Simon C. Estok, the tragedy conveys the "ecophobia" of an audience traumatized by "bad harvests" and "cold weather," and the play proves particularly "vivid in its foregrounding of environmental unpredictability and in its dramatization of a fear of nature.",60

\footnotetext{
${ }^{55}$ Randle Cotgrave, A Dictionarie of the French and English Tongues, London, Printed by Adam Islip, 1611, n.p., CLI.

${ }^{56}$ Brendan Dooley, "Conclusion" in A Companion to Astrology in the Renaissance, ed. Brendan Dooley, Leiden, Brill, 2014, p. 430 (p. 429-34).

${ }^{57}$ Stow and Howes quoted in René Weis, Shakespeare Unbound. Decoding a Hidden Life, New York, Henry Holt and Company, 2007, p. 335.

${ }^{58}$ Robert Markley, "Summer's Lease: Shakespeare in the Little Ice Age," p. 137.

${ }^{59}$ See "climate" in Randle Cotgrave, A Dictionarie of the French and English Tongues, ed. cit., n.p., CLI.

${ }^{60}$ Simon C. Estok, Ecocriticism and Shakespeare. Reading Ecophobia, New York, Palgrave Macmillan, 2011, Kindle edition, 438/4160 (chapter 2).
} 
Yet, we are probably wrong to confuse reality with truthfulness. For all its truthfulness, King Lear does not depict reality. With its rich language and beautiful imagery, it is a dramatic poem and, as Touchstone ironically remarks in As You Like It, "the truest poetry is the most feigning" (3.3.16-17). ${ }^{61}$ As a playwright, Shakespeare did not simply want to hold a mirror up to nature when he wrote his plays. His onstage storms partake of an aesthetic process which turns the play into an anti-pastoral of sorts and transforms the landscape into an mindscape open to scrutiny and anatomy.

If we look at the playtext, we notice that the stage direction "Storm still" is repeated six times in the Folio edition. To many critics, it simply "evokes [...] the severe weather that, if not commonplace, was a far more familiar experience for Shakespeare and his audiences than it [is] for his twentieth-century critics." ${ }^{, 62}$ But what is often forgotten is that, in King Lear, the stage directions related to storms are indeed present in the Folio but are absent from the Quartos. As a result, we are entitled to think that Shakespeare initially conceived these storms as purely interior, metaphorical storms. "O, let me not be mad, not mad, sweet heaven! / Keep me in temper. I would not be mad," Lear begs the sky not long before the weather deteriorates (1.5.45-46). These two lines convincingly suggest that the title-character sees in the sky the reflection of his own mind. More pragmatically, staged storms would have involved a swivel, a squib "to produce the effect of lightning" and a cannonball (rolled around the floor of the "heavens" or sent down a "thunder run"), ${ }^{63}$ which means that an enclosed space would have been much more adapted than the Globe to recreate the impressive noises of a real storm. ${ }^{64}$ That's the reason why King Lear was probably not first designed as a play emphasizing the disasters of a literal climate, but rather as a play which conflates the storm with Lear's inner experience. In other words, Lear is the storm.

So, when he asks the storm to "drench [...] our steeples" and send down "oak-cleaving thunderbolts" to "strike flat the thick rotundity o'th'world" (3.2.7), he is not victimized by the weather. On the contrary, he re-appropriates it to use it for his personal ends. He therefore emphasizes the transformative power of the storm whose rain is meant to purge the earth.

\footnotetext{
${ }^{61}$ William Shakespeare, As You Like It, ed. Alan Brissenden, Oxford, Oxford University Press, 1993.

${ }^{62}$ Robert Markley, "Summer's Lease: Shakespeare in the Little Ice Age," p. 135.

${ }^{63}$ See Mary Thomas Crane, "Optics" in Early Modern Theatricality, ed. Henry S. Turner, Oxford, Oxford University Press, 2013, p. 265 (p. 250-69).

${ }^{64}$ Bruce R. Smith specifies that "the very loudest sound that a sixteenth- or seventeenth-century listener might encounter [...] fall with a range of decibel intensities that would nowadays almost rate as normal events," and these sounds were "thunder, cannon-fire, and bells." See Bruce R. Smith, The Acoustic World of Early Modern England: Attending to the O-Factor, Chicago, University of Chicago Press, 1999, p. 49.
} 
Water, here, is also holy water, the water of baptism, ${ }^{65}$ as the repentant Lear gradually learns mercy. Thunder, water and wind are, so to speak, the agents of truth in the play. They wake up Lear and they at last make him a self-conscious, clear-sighted man. Lear's final moments, when he breathes his last while searching for Cordelia's breath, eventually dramatize the centrality of moving air - the Greek pneuma, which means both "wind" and "breath" - in the creation of a coherent, yet ever-shifting, self. ${ }^{66}$

\section{Conclusion}

In the early modern period, the earth was divided into "frozen," "temperate" and "burning" zones. ${ }^{67}$ This scheme "determined the logic of geohumoralism" and this implied, in turn, that "humoral temperance [...] was held to be attainable only in a temperate clime." ${ }^{68}$ Shakespeare had no certainties about the weather and he henceforth relied on many different, and sometimes contradictory, theories of the time. But, as a playwright, he was definitely interested in the frozen and burning zones because they are the ones likely to generate climactic scenes in his plays.

Significantly, clement weather, in his work, is always transient. In fact, the playwright focuses on the stability of unstable, or bad, weather, in order to convey tensions, be they political, social, or aesthetic. Thanks to recurring allusions to well-established climactic patterns, he manages to put to the fore a complex, changing, and interactive relationship between man and Nature. In A Midsummer Night's Dream, the weather is clearly disturbed by human behaviour-"human," because Titania and Oberon are constantly belittled and treated as mortals. On the contrary, in Romeo and Juliet, weather dictates the mood and the fate of the characters, and the dog days described in the play signal the forthcoming end of the

\footnotetext{
${ }^{65}$ In connection with this, see the Fool's remark: "O nuncle, court holy water in a dry house is better than this rain-water out o' door" (3.2.10-12). Interestingly, Thomas Becon assured a dying man that baptism was "a sure token of the fauour of God toward you, and that you are predestinate vnto euerlasting life [...] Baptisme is a continuall signe of the fauour of God towarde vs, of the fre remission of sines, of our reconciliation vnto God for Christes sake, and that we be by adoption the sonnes of God." Quoted in Alec Ryrie, Being Protestant in Reformation Britain, Oxford, Oxford University Press, 2013, p. 323.

${ }^{66}$ See Steve Mentz, "Strange weather in King Lear," Shakespeare, 6:2, 2010, p. 142 (139-52). On the importance of "pneuma" in Shakespeare, see, too, James A. Knapp, "Mental Bodies in Much Ado About Nothing" in Embodied Cognition and Shakespeare's Theatre: The Early Modern Body-Mind, eds. Laurie Johnson, John Sutton, and Evelyn Tribble, New York, Routledge, 2014, p. 89 (p. 86-104): "The idea of spirit as life-giving breath, a third term between soul and body, can be traced to antiquity, coming down to the early moderns from Aristotle and his interpreters. Aristotle's theory of pneuma influenced the use of the term spirit in commentaries on both medicine and the soul (most notably Aquinas and Avicenna), which use the term spirit to refer to either a fine material substance or an incorporeal body, such as an angel."

${ }^{67}$ See for instance William Cunigham's 1559 The cosmographical glasse.

${ }^{68}$ Mary Floyd-Wilson, English Ethnicity and Race in Early Modern Drama, p. 2.
} 
eponymous lovers. The relationship between man and nature is much more ambivalent, and much more subtly treated in King Lear, a mature tragedy in which the playwright presents the influence of weather upon man, and of man upon weather, in an acute awareness of the environmental problems posed by man's behaviour. When Shakespeare wrote this particular play, lands so far unknown had been colonized, science and technology had been through unprecedented advances, and the control of nature had become much more attainable a goal. No wonder then if, in King Lear, the weather is presented in an anthropomorphic way: "Blow, winds, and crack your cheeks!" Lear exclaims (3.2.1). The wind is both a generative ${ }^{69}$ and a destructive force, depending on man's ability to adapt and evolve. Climate, here, bridges the gap between man and nature. It becomes an actor and is no longer a simple excuse for powerful stage effects. It is a force to be reckoned with, a major element of the world's balance. Ultimately, if climate owes nothing to supernatural causes, it proves an experimental, technical and a sensual experience at the same time.

\footnotetext{
${ }^{69}$ In Michael Maier's Atalanta fugiens (Oppenheim, 1617), an alchemical emblem book containing 50 emblems illustrating the alchemical process, the first emblem (accompanied by the motto "Portavit eum ventus in ventre suo", / "The Wind carries it in his belly," p. 1) depicts the Wind. Curiously, he is pregnant and a child can be seen in his belly, which makes him a generative force. See H.M.E. de Jong (ed.), Michael Maier's Atalanta fugiens: Sources of an Alchemical Book of Emblems, Leiden, Brill, 1969.
} 